Acta Veterinaria (Beograd), Vol. 63, No. 5-6, 609-620, 2013.

\title{
EXAMINATION OF ENZYMES CONCENTRATION IN THE BLOOD OF RATS WITH SEPSIS CAUSED BY MIXED AND PURE BACTERIAL CULTURES
}

STOJANOVIĆ DRAGICA*, KOVAČEVIĆ ZORANA*, ŽEKIĆ MARINA**, AŠANIN JELENA**, RATAJAC $R^{* *}$, PETROVIĆ JELENA**, PETROVIĆ $T^{* *}$, STOJANOV I** and VELHNER MAJA**

* University of Novi Sad, Faculty of Agriculture, Serbia

** Scientific Veterinary Institute „Novi Sad“, Novi Sad, Serbia

*** University of Belgrade, Faculty of Technologicy and Metallurgy, Innovation center, Serbia

(Received $12^{\text {th }}$ December 2012)

A clinical form of sepsis induced by cecal ligation and puncture (CLP) was caused in order to monitor the concentration of enzymes (alanine aminotransferase - ALT, aspartate aminotransferase - AST, lactate dehydrogenase - $L D H$, amylase and creatine kinase - CK) in the rat blood. Experiments were performed on male Wistar rats, weighing on average $215 \pm 25 \mathrm{~g}$. The rats were divided into four groups. In the first three groups ( $n=28$ per group), sepsis was induced by pure culture of Escherichia coli (EC) or Staphylococcus aureus (SA) and mixed culture (MK) of caecum, while the fourth group included 20 control rats who underwent an abdominal incision. Blood was taken in time intervals of 12, 24, 72 and 120 hours.

During the experimental protocol, we identified significant changes of all monitored enzymes in the serum of infected rats. After a period of 12 hours there was a significant increase in ALT (all rats with sepsis), AST and $L D H$ (rats in the MK group) levels, while a decrease was noted in the concentration of amylase (EC, SA). Similarly, 24 hours after the CLP procedure, a significant decrease of amylase (MK) and AST (SA) was recorded, while serum $L D H$ level varied significantly from elevated $(E C, S A)$ to reduced $(M C)$ values. Finally, at the time intervals of 72 and 120 hours the concentration of nearly all monitored enzymes has shown a decline, while significance was noted in lowering of ALT (MK), AST (SA, EC) and amylase (SA) levels. Statistical significance could not be observed in the change of $\mathrm{CK}$ levels at any of examined time points.

Key words: Enzyme, Escherichia coli, mixed sepsis, rats, Staphylococcus aureus 


\section{INTRODUCTION}

Sepsis, as a result of acute infectious processes in the blood, could often be a cause of a series of pathophysiological disorders, which consequently lead to a continuous damage of vital organs (liver, lungs, kidneys, brain) (Goodman et al., 2003; Bagshaw et al., 2007; Albert et al., 2003). Namely sepsis could be caused by a range of Gram positive and Gram negative a bacteria , viruses, rickettsie and pathogenic fungi. The order of bacteria that most commonly cause sepsis changes from decade to decade. For instance, streptococcal sepsis was the most present sepsis of the preantibiotic era, but nowadays leading causes of sepsis are staphylococci and Gram -negative bacteria, particularly multi-resistant hospital strains (Cohen, 2002). Based on the results of previous clinical and experimental research, it is believed that the pathogenic mechanisms of sepsis are primarily contained in the complex process of cellular activation, which results with the release of proinflammatory mediators such as cytokines, activation of neutrophils, monocytes and microvascular endothelial cells, and includes the neuroendocrine reflex followed by activation of complement, coagulation and fibrinolysis (Abraham and Singer, 2007). Additionally, there is still growing interest in studying sepsis caused by surgical intervention, individuals in intensive care units, sepsis after intravenous or urinary catheterization, fatal injuries, transplantation and stress (Vincent and Abraham, 2006) . In fact, many pathogenic aspects of sepsis are yet to be understood (Lever and Mackenzie, 2007), its diagnosis and prognosis remain uncertain and high percentage of mortality continues to be recorded in the intensive care units (Afessa et al., 2001; Angus et al., 2001; Sakr Y, 2012, Vincent et al., 2006).

Taking into account the fact that sepsis in humans requires obligatory medical treatment which leads to changes in the pathophysiological processes of patients, it is clear that the information about the systematic inflammatory response is contained within the animal models of sepsis. Similarly, the development of new approaches in solving and treating sepsis requires the use of quantitative and qualitative studies on sepsis animal models (Cohen et al., 2011). Namely, numerous sepsis models present laboratory findings and perceived signs and symptoms of sepsis in humans, but they are rarely fully equivalent to the clinically manifested sepsis. Some of these models develop sepsis instantly, thus developing sepsis into septic shock, some stop at the level of bacteremia, and some are difficult to reproduce, Hence additional laboratory standardization needs to be addressed (Fink, 1990). Peritonitis models are the first realistic and relevant models, adequate to clinically manifested sepsis. They exhibit the development and features of the experimental model with the characteristics of chronic peritoneal sepsis (Dejager et al., 2011). Clinical observations and some experimental data indicate that the hypermetabolic phase of sepsis is present in the early period, and comes prior to hypodynamic or shock phase. According to numerous researchers, the model of cecal ligation and puncture (CLP) is the most 
suitable for the investigation of the septic process. Possible changes in diameter and the number of needle punctures can result in rapid transfer from sepsis to septic shock. Additionally, this model is not complicated, it is standardized in rats, reproducible and demonstrates hemodynamic, hormonal and metabolic features of sepsis observed in humans (Bourse et al., 2005; Doi et al., 2009).

\section{MATERIALS AND METHODS}

Experiments were performed on male Wistar rats, average body mass 215 $\pm 25 \mathrm{~g}$. The rats were divided into four groups, three of which included 28 animals and one control group of 20 animals. Three groups of rats were subjected to the surgical procedure of opening the abdomen and a ligation of the cecum (1/3 below the ileocecal valve), with the exception the, control group $(K)$ where the ligation was not performed. Thus, the last group of 20 control animals underwent only an abdominal incision (a sham operation). In one group of rats (MK), sepsis was induced by the content of the ligated and punctured cecum (mixed culture of microorganisms). The employed technique is by Wichterman et al. (1980) with slight modifications. In the remaining two groups of rats, sepsis was induced by inoculation of pure cultures of Escherichia coli (EC) and Staphylococcus aureus (SA) to the previously emptied, ligated and washed cecum (Stojanovic et al., 2002). Surgical intervention was performed on rats anesthetized with thiopental barbital, i.p., $50 \mathrm{mg} / \mathrm{kg}$.

In order to determine the concentration of the enzymes (alanine aminotransferase - ALT, aspartate aminotransferase - AST, lactate dehydrogenase $\mathrm{LDH}$, amylase and creatine kinase - CK), the animals were sacrificed in time intervals of $12,24,72$ and 120 hours and blood was sampled by puncture of the abdominal aorta. Concentrations of these enzymes have been measured automatically by the biochemical analyzer - SMAC (Sequential Multiple Analysis plus Computer).

Descriptive data were expressed as the mean \pm standard deviation (SD). Statistical analysis was performed using a statistical software program (Statistic 5.0 for Windows). Groups were compared by Student's t-test and two-way analysis of variance. Differences were considered statistically significant at $p<0.05$

\section{RESULTS}

During the experimental protocol, we identified significant changes of all monitored enzymes in the serum of infected rats. More specifically, the concentration of ALT showed an increase in the first half of the experimental protocol (at intervals of 12 and 24 hours) in comparison to the controls (sham surgery), and a statistically significant increase for all three tested groups (EC, SA, MK) at time intervals or 12 hours (Figure 1). Conversely, in terms of late sepsis (72 and 120 hours), almost all groups saw a decrease in the concentration of ALT, which gained statistical significance in the EC and the MC group after 72 hours (Figure 1). 


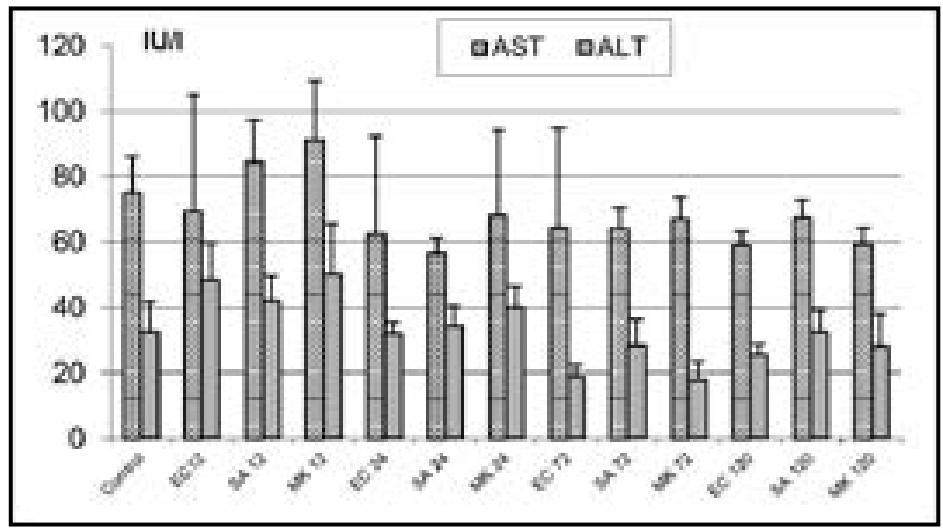

Figure 1: Results of concentration of alanine aminotransferase - ALT and aspartate aminotransferase - AST in blood sera of the experimental rats

MK - Mixed sepsis; EC - Sepsis induced by Escherichia coli; SA - Sepsis induced

by Staphylococcus aureus; $12,24,72,120-$ Time after surgery $(h)^{*} p<0.05$ compared with control

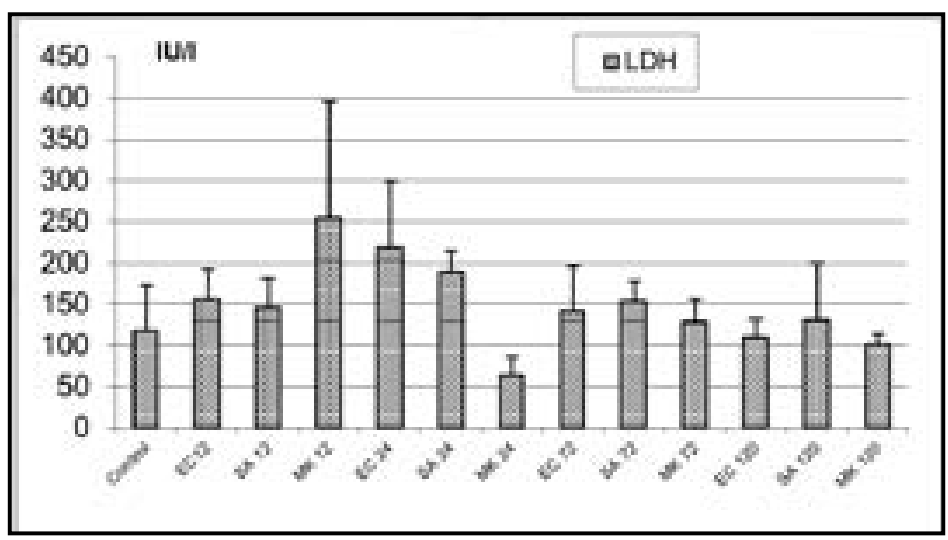

Figure 2: Results of concentration of lactate dehydrogenase - LDH in blood sera of the experimental rats control

MK - Mixed sepsis; EC - Sepsis induced by Escherichia coli; SA - Sepsis induced

by Staphylococcus aureus; $12,24,72,120$ - Time after surgery $(h)^{*} p<0.05$ compared with control 


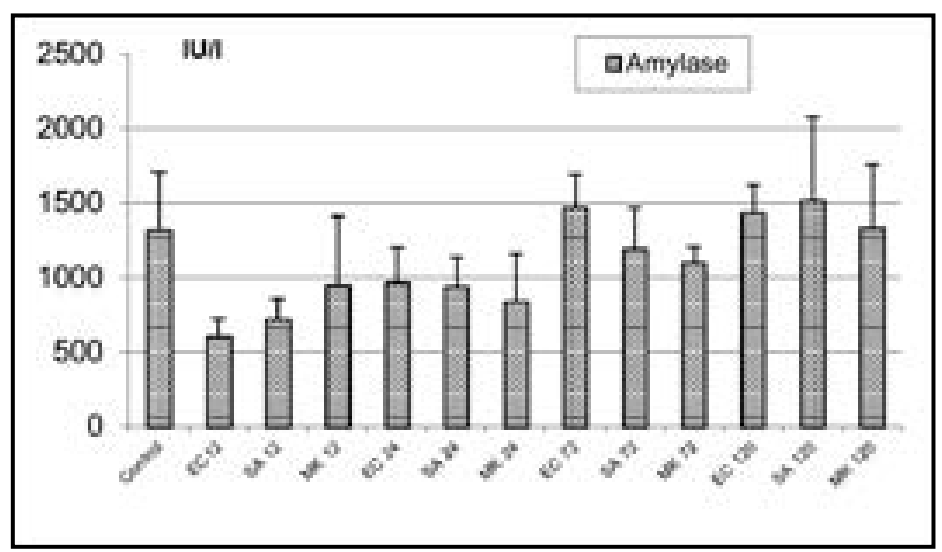

Figure 3: Results of concentration of amylase in blood sera of the experimental rats MK - Mixed sepsis; EC - Sepsis induced by Escherichia coli; SA - Sepsis induced by Staphylococcus aureus; $12,24,72,120-$ Time after surgery $(h)^{*} p<0.05$ compared with control

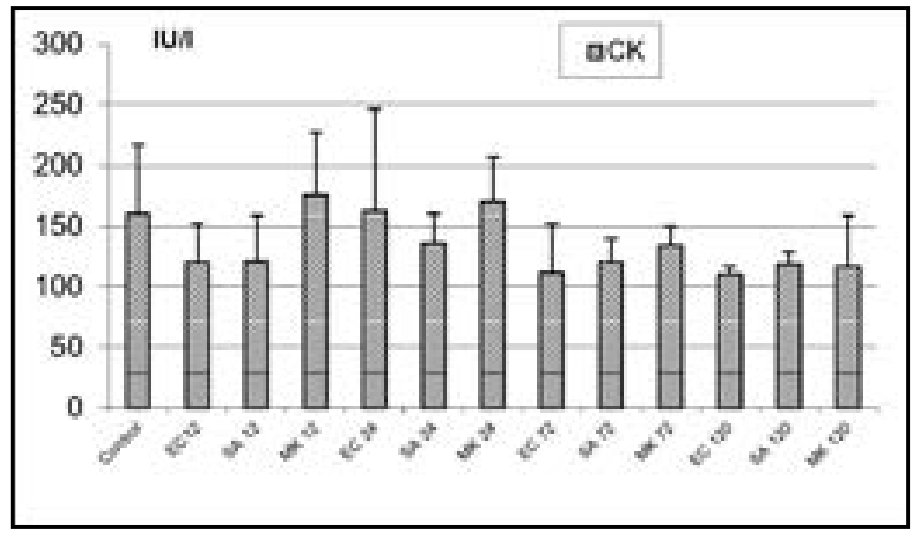

Figure 4: Results of concentration of creatine kinase-CK in blood sera of the experimental rats

MK - Mixed sepsis; EC - Sepsis induced by Escherichia coli; SA - Sepsis induced by Staphylococcus aureus; $12,24,72,120$ - Time after surgery $(h)^{\star} p<0.05$ compared with control 
Figure 1 also illustrates the change in the concentration of AST in the serum of tested rats, revealing that a decrease in this enzyme concentration could be observed at almost all time points compared to the controls, with the exception of MC group after 12 hours where a significant increase has been noted. Statistically significant reduction in the serum level of AST was recorded in the SA Group after 24 and 72 hours and in the EC group after 120 hours.

The concentration of LDH (Figure 2) in infected rats was more or less above the one found in control group for all observed periods and statistically significant in the case of MC group (after 12 hours), EC and SA group (after 24 hours). Significant reduction of LDH level was found in MC group 24 hours after the beginning of the experiment.

A decrease of amylase concentration in rats with sepsis has been seen in the first half of the experiment (after 12 and 24 hours) and reached statistical significance in the EC group (after 12 hours) and MC group (after 24 hours). In the second half of the experiment (after 72 and 120 hours), amylase concentration in septic rats was above the level found in the control group, except in SA and MC group after 72 hours (Figure 3 ).

In our experiments, there was no significant change in the levels of $\mathrm{CK}$ within the control group (Figure 4). Yet, in septic rats through all observed periods significantly lower levels of CK have been recorded (except in the MC group after 12 and 24 hours and EC after 24th hour).

\section{DISCUSSION}

Examination of clinical and laboratory parameters (including hematological and biochemical parameters) in the CLP model of sepsis, under the conditions of heterogeneous response similar to human sepsis, is the basis for investigation of the sepsis pathogenesis according to most of the authors (Meisner, 2005; Pierrakos and Vincent, 2010, Stojanovic et al., 2004; Stojanovic et al., 2012). This is contributed by numerous studies of inhibitors in sepsis, which certainly complement the diagnosis and prognosis and facilitates the treatment under the clinical conditions (Rivers et al., 2005). Furthermore, a recent research suggests that pathogenic events during sepsis depend primarily on the level of catabolic mediators. The outcome of released mediators may be dual - they can be inactivated, but they can also preserve its activity towards endothelial cells, thus creating conditions for hypotension and septic shock (Marshall, 2001; Webb, 2002). Central role in this process (Cavaillon et al.,2003) is attributed to the tumor necrosis factor (TNF) and interleukin-1 (IL-1). These substances regulate the proinflammatory protective immune response to infection and host defense activation of neutrophils, macrophages and lymphocytes, amplify gene expression and release of acute phase proteins and granulocyte colony stimulating factor (GCSF), induce anti-inflammatory cytokines IL-4, IL-6, IL-10, IL-1ra and lower the level of TNF and IL receptors by transformation of growth factor b (Opal and 
De Palo, 2000; Bhatia M, Moochhala S, 2004). On the other hand, numerous sources confirm that proinflammatory cytokines play a central role in cell death with consequent organ damage (Oberholzer et al., 2001; Hagimato et al., 2005), which can possibly be explained by a lower concentration of enzymes tested in our experiments. Namely, in the investigated time intervals for late sepsis in the presented study $(72,120 \mathrm{~h}$ ), we found low plasma levels of ALT, AST, LDH and CK (Figure 1 and Figure 2). Conversely, in the examined periods of 12 and 24h, the levels of ALT, AST and LDH (Figure 1 and Figure 2) in infected rat serum were generally above the level of controls. Finally, values of amylase (Flgure 3 ) and CK (Figure 4) concentrations varied depending on the tested model. In a similar experiment, Holly et al. (2006) detected an increase in the concentrations of ALT, AST and alkaline phosphatase $24 \mathrm{~h}$ hours after the CLP procedure, while levels of ALT and AST reached even higher values in the population of rats with acute renal insufficiency (ARI). In accordance to our findings, 24 hours after the start of the experiment CK level decreased, LDH level increased with significantly higher amylase concentration in rats with ARI. Moreover, cytokine IL-6 and IL-10 were significantly higher in rats with AFI, and tumor necrosis factor (TNF- $\alpha$ ) levels at 8 and 24 hours were not detectable. At the same time points Holly et al., also found an increase in nitrite concentration, suggesting that nitric oxide (NO) may be involved in the pathophysiology of sepsis. Hepatic injuries were detected in the periods of 8 to 24 hours and kidney injuries only at the later time point. Both findings were confirmed by pathohistological examination. The observed changes were attributed to the induction of pro-and anti -inflammatory cytokines, which could be documented in previous sepsis related studies.

Rodrigues et al. (2012) 24 hours after the CLP procedure, recorded a significant increase in ALT, AST, LDH, but also a comparable increment in creatinine, lactate, IL-1 $\beta, I L-2, I L-6, I L-10$, interferon gamma (INF- $\gamma$ ), and TNF- $\alpha$ in the rats' serum. Based on their research, the authors suggested that CERA (continuous erythropoietin receptor activator) might have an important role as a protective factor in multiple organ dysfunctions, which can be ascribed to the inhibition of inflammatory responses. Namely, CERA decreases the nuclear factor kappa (NFkappa B) expression via the toll-like receptor 4 (TLR4) pathways thereby inhibiting macrophage infiltration into the renal interstitium and decreasing systemic production of inflammatory cytokines. Gao et al. (2012) have noted a significant increase of AST, ALT, LDH, CK and creatinine serum level 12 hours from the CLP procedure in rats. Additionally, their study observed significantly higher values of cytokines TNF- $\alpha, \mathrm{IL}-1 \beta$, IL-6, monocyte, chemoattractant protein-1 (MCP -1) and high-mobility group box protein 1 (HMGB1) for septic rats when compared to sham operated ones. Based on correlation analysis of measured parameters, it was concluded that body temperature $(T)$, blood urea nitrogen (BUN), creatinine, ALT, CK, IL-6 and MCP-1 levels after the CLP were negatively correlated with survival, while platelet count (PLT), HMGB1 and granulocyte-macrophage colony stimulating factor (GMCCF) were positively correlated with the survival outcome. 
The authors point out that the combination of different biomarkers improves accuracy of diagnosis in clinical trials, and this appears more effective in predicting survival in septic rats. For use in diagnostic procedures, the authors favor the combination comprising: BUN, creatinine, IL-6 and GMCSF.

Siddiqui et al. (2006), based on the monitored parameters (ALT, AST, lactate, albumin, and TNF- $\alpha$ ), demonstrated the involvement of TNF - $\alpha$ in the pathogenesis of CLP induced sepsis in rats, but also proved a potential impact of a pharmacologically active substance - cuecumin. The intravenous application of cuecumin attenuated tissue injury, reduced mortality and decreased the expression of TNF - alpha in septic animals. Furthermore, the proposed protective effect of the active substance was detected in vitro in cultured macrophage cell line RAW 264.7. In a study that tested a protective effect of androstenediol, Szalay et al. (2006), investigated the levels of cytokines (IL-6 and IL-10), the activity of myeloperoxidase (MPO), neutrophil chemotactic factor (CINC-3) and liver injury (ALT and LDH), 5 hours after the CLP procedure. These authors suggested that within the CLP procedure which is associated with hemorrhage and trauma $(\mathrm{HT})$, a significant increase of IL- 6 and IL-10 concentrations, neutrophilic activation in the lungs and heart, and subsequent liver damage. Also, in addition to the increased production of proinflammatory mediators and reduced perfusion of organs, it plays an important role in the development of MODS (multiple organ dysfunction bodies). Cohen et al. (2011) have recorded a significant increase in ALT, LDH, IL-6 levels 24 hours after the CLP procedures and proved that s.c. and i.v. applications of Gelsolin (actin-binding protein) have a protective effect by reducing the concentrations of these enzymes and cytokines.

Yoshikawa et al. (2012) demonstrated that treatment with a high-dose of human immunoglobulin $(1.500 \mathrm{mg} / \mathrm{kg})$ significantly improves the survival of rats in the CLP model. Also, after the administration of high doses of immunoglobulin and 4 hours after the CLP procedures significantly lower values of albumin, AST, ALT, LDH, creatinine, BUN and HMGB1 were observed in the blood of tested rats.

In their studies Chian et al. (2013) support the hypothesis that changes in biochemical and hematological parameters during early sepsis have an impact on tissue perfusion and organ damage in late sepsis. Specifically, based on the monitored parameters (primarily LDH, BUN and total protein), 18 hours after the CLP procedure, the authors proved that the pretreatment of rats with $25 \%$ albumin (3 hours before CLP procedure) significantly reduces macro and microhemodynamic changes and attenuates intestine and lung injuries in peritonitis induced sepsis. Involvement of lactic acidosis in sepsis was confirmed in earlier experiments of Deshpande et al., (2000). On the basis of these experiments authors conclude that heat stress ameliorates lactic acidemia, improves oxygen delivery or prevents cellular dysfunction, possibly by preserving the organ perfusion, in a rat model of sepsis.

Wang et al. (2012) demonstrated the effect of TNF- $\alpha$ and IL-6 on the permeability of the intestinal barrier in the CLP sepsis model in rats. The treatment 
of septic rats with glutamine reasonably reduces plasma d-lactate concentration of lipopolysaccharide (LPS). In similar tests Jiang et al. (2009) demonstrated the importance of cytokines TNF- $\alpha$ and IL-6 (and IL-10, and HGMB1 TREM1) using the same CLP model. Namely, compared to the sham operated rats, they recorded significantly higher serum values of ALT, AST, BUN and CK and CK-MB 20 hours after the CLP procedure. Pretreatment of septic rats with paeoniflorin improves hemodynamics, reduces the levels of serum enzymes and reduces the concentration of myeloperoxidase in the lungs, liver and small intestine. Additionally, in this study paeoniflorin have exhibited dose dependency in the regulation of the level of TNF - $\alpha$, IL- 6, IL -10, HGMB1.

In their investigations Coelho et al. (2013) recorded a significant increase in the concentration of CK in homogenates of soleus and plantar muscles $120 \mathrm{~h}$ after CLP, and increased the activity of superoxide dismutase (SOD). Based on the measured parameters of oxidative stress, the authors concluded that aerobic physical pretreatment of septic rats prevents atrophy, lipid peroxidation and protein oxidation, and significantly improves the SOD activity in skeletal muscle.

In conclusion, our study recorded a significant change in the concentration of all tested enzymes, depending on the applied sepsis model. The values obtained in the period of early sepsis, viewed from the perspective of other authors, might refer to the importance of proinflammatory cytokines in sepsis. However, the obtained values of the enzyme in the period of late sepsis certainly complements the remaining issues surrounding the enigma of sepsis pathogenesis. However, the obtained values of the studied enzymes in different CLP sepsis models open the possibility for investigations of the potential activity of a number of pharmacologically active substances.

Acknowledgement:

This work is supported by a grant from the Ministry of Education and Science, Republic of Serbia, Projects No TR 31071 and TR 31079.

Address for correspodence:

Dr Dragica Stojanović,

University of Novi Sad Faculty of Agriculture Dositej Obradović, Square 8.

21000 Novi Sad, Serbia

E-mail: dragica@niv.ns.ac.rs

\section{REFERENCES}

1. Abraham E, Singer M, 2007, Mechanisms of sepsis-induced organ dysfunction, Crit Care Med, 7, 35, 2408-16.

2. Afessa B, Green B, Delke I, Koch K, 2001, Systemic inflammatory response syndrome, organ failure, and outcome in critically ill obstetric patients treated in an ICU, Chest, 120, 1271-7.

3. Alberta C, Brun-Buisson C, Goodman SV, Guidici D, Granton J, Moreno R, et al., 2003, Influence of systemic inflammatory response syndrome and sepsis on outcome of critically ill infected patients, Am J Respir Crit Care Med, 168, 77-84. 
4. Angus DC, Linde-Zwirble WT, Lidicker J, Clermont G, Carcillo J, Pinsky MR, 2001, Epidemiology of severe sepsis in the United States:analysis of incidence, outcome, and associated costs of care, Crit Care Med, 29, 1303-10.

5. Bagshaw SM, Uchino S, Bellomo R, Morimatsu H, Morgera S, Schetz M et al.,2007, Septic acute kidney injury in critically ill patients:Clinical characteristics and outcomes, Clin J Am Soc Nephrol, 2,431-9.

6. Bhatia M, Moochhala S, 2004, Role of inflammatory mediators in the pathophysiology of acute respiratory distress syndrome, $J$ Pathol, 202, 145-56.

7. Buras JA, Holzmann B, Sitkovsky M, 2005, Animal models of sepsis: setting the stage. Nat Rev Drug Discov, 4,10, 854-65.

8. Cavaillon JM, Adib-Conquy M, Fitting C, Adrie C, Payen D, 2003, Cytokine cascade in sepsis, Scand J Infect Dis, 35, 9, 535-44.

9. Chian CF, Tsao CM, Chen SJ, Chen ZF, Liaw WJ, Ka SM et al., 2013, Hyperoncotic albumin attenuates lung and intestine injuries caused by peritonitis-induced sepsis in rats. J Surg Res, 182, 1, 182-41.

10. Coelho CW, Jannig PR, Souza AB, Fronza H, Westphal GA, Petronilho F et al., 2013, Exercise training prevents skeletal muscle damage in an experimental sepsis model, Clinics, 68,1,107-14.

11. Cohen J, 2002, The immunupathology of sepsis, Nature, 420, 885-91.

12. Cohen TS, Bucki R, Byfield FJ, Ciccarelli NJ, Rosenberg B, DiNubile MJ et al., 2011, Therapeutic potential of plasma gelsolin administration in a rat model of sepsis, Cytokine, 54, 235-8.

13. Dejager L, Pinheiro I, Dejonckheere E, Libert C, 2011, Cecal ligation and puncture: the gold standard model for polymicrobial sepsis, Trends Microbiol, 19, 4,198-208.

14. Deshpande GG, Heidemann SM, Sarnaik AP, 2000, Heat stress is associated with decreased lactic acidemia in rat sepsis, Crit Care, 4, 45-9.

15. Doi K, Leelahavanichkul A, Yuen PS, Star RA, 2009, Animal models of sepsis and sepsisinduced kidney injury, J Clin Invest, 119,10, 2868-78.

16. Fink MP, Heard SO, 1990, Laboratory models of sepsis and septic shock, J Surg Res, 49, 2, 186-96.

17. Gao M, Zhang L, Liu Y, Yang M, Wang N, Wang K et al., 2012, Use of blood urea nitrogen, creatinine, interleukin-6, granulocyte-macrophage colony stimulating factor in combination to predict the severity and outcome of abdominal sepsis in rats, Inflamm Res, 61, 889-97.

18. Goodman RB, Pugin J, Lee JS, Matthay MA, 2003, Cytokine-mediated inflammation in acute lung injury, Cytok Grow Fact, 14, 6, 523-35.

19. Hagimato MN, Nakamura M, Bello GM, 2005, Apoptosis and epithelial injury in the lungs, Proc Am Thor Soc, 2, 214-20.

20. Holly MK, Dear JW, Hu X, Schechter AN, Gladwin MT, Hewitt SM et al., 2006, Biomarker and drug-target discovery using proteomics in a new rat model of sepsis-induced acute renal failure, Kidn Int, 70, 496-506.

21. Jiang WL, Chen XG, Zhu HB, Gao YB, Tian JW, Fu FH, 2009, Paeoniflorin inhibits systemic inflammation and improves survival in experimental sepsis, J Nord Pharmacol Soc Bas Clin Pharmacol Toxicol, 105, 64-71.

22. Lever A, Mackenzie I. Sepsis: definition, epidemiology, and diagnosis, BMJ. 2007;335:879-83.

23. Marshall JC, 2001, Inflammation, coagulopathy, and the pathogenesis of multiple organ dysfunction syndrome, Crit Care Med, 29, 99-106.

24. Meisner M, 2005, Biomarkers of sepsis: clinically useful? Curr Opin Crit Care, 11, 473-80.

25. Oberholzer A, Oberholzer M, Salzler Clare, Moldawer, 2001, Apoptosis in sepsis: a new target for therapeutic exploration, FASEB J, 15, 6, 879-92.

26. Opal SM, De Palo VA, 2000, Anti-inflammatory cytokines, Chest, 117, 4, 1162-72.

27. Pierrakos C, Vincent $J L, 2010$, Sepsis biomarkers: a review, Crit Care, 14:R15.

28. Rivers EP, McIntyre L, Morro DC, Rivers KK, 2005, Early and innovative interventions for severe sepsis and septic shock: taking advantage of a window of opportunity, CMAJ, 25, $173,9,1054-65$. 
29. Rodrigues CA, Sanches TR, Volpini RA, Shimizu MH, Kuriki PS, Camara NO et a. I, 2012, Effects of continuous erythropoietin receptor activator in sepsis-induced acute kidney injury and multi-organ dysfunction, Plos One, 7,1, 1371-9.

30. Sakr Y, Lobo SM, Moreno RP, Gerlach H, Ranieri MV, Michalopoulos A et al, 2012, Patterns and early evolution of organ failure in the intensive care unit and their relation to outcome, Crit Care, 16, R 222 .

31. Siddiqui AM, Cui X, Wu R, Dong W, Zhou M, Hu M, et al., 2006, The anti-inflammatory effect of curcumin in an experimental model of sepsis is mediated by up-regulation of peroxisome proliferator-activated receptor-gamma, Crit Care Med, 34, 7, 1874-82.

32. Szalay L, Shimizu T, Suzuki T, Hsieh YC, Choudhry MA, Schwacha MG et al., 2006, Androstenediol administration after trauma-hemorrhage attenuates inflammatory response, reduces organ damage, and improves survival following sepsis, Am J Physiol Gastrointest Liver Physiol, 291, 266-6.

33. Stojanović $D$, Malicević Ž, Ašanin R, 2002, The use of a new model for investigation of sepsis, Acta Vet (Belgrade), 52, 2-3, 125-32.

34. Stojanovic D, Ašanin R, Malicević Ž, Vidić B, 2004, Model of sepsis (caecal ligation and puncture) in rats caused by mixed and pure bacterial cultures and changes in white blood cell counts, Acta Vet (Belgrade), 54, 4, 281-7.

35. Stojanovic D, Velhner M, Stojanov I, Petrović J, Ašanin R, Kovačević Z, 2012, Biochemical parameters in rats with an applyed model of sepsis (caecal ligation and puncture) with pure and mixed bacterial culture, Acta Vet (Belgrade), 62, 5-6, 543-51.

36. Vincent JL, Sakr Y, Sprung CL, Ranieri VM, Reinhart K, Gerlach $H$ et al, 2006, Sepsis in European intensive care units: results of the SOAP study, Crit Care Med, 34, 344-53.

37. Vincent JL, Abraham E, 2006, The last 100 years of sepsis, Am J Respir Crit Care Med, 173, 3, 256-63.

38. Wang $X, X u e Y$, Liang $M$, Jiang $W, 2012$, Glutamine treatment decreases plasma and lymph cytotoxicity during sepsis and rats, Acta Biochim Biophys Sin, 44, 9,774-82.

39. Webb S, 2002, The role of mediators in septicemia resolution, Advances in Sepsis, 2, 8-14.

40. Wichterman KA, Baue AE, Chaudry IH, 1980, Sepsis and septic shock-A review of laboratory models and a proposal, $J$ Surg Res, 29, 189-201.

41. Yoshikawa T, Takeuchi H, Suda K, Miyasho T, Yamada S, Okamoto M et al, 2012, High-dose immunoglobulin preparations improve survival in a CLP-induced rat model of sepsis, Langenbecks Arch Surg, 397, 3, 457-65.

\title{
ISPITIVANJE KONCENTRACIJE SERUMSKIH ENZIMA KOD PACOVA SA SEPSOM KOJA JE IZAZVANA MEŠANOM I ČISTIM KULTURAMA BAKTERIJA
}

\author{
STOJANOVIĆ DRAGICA, KOVAČEVIĆ ZORANA, ŽEKIĆ MARINA, AŠANIN JELENA, \\ RATAJAC R, PETROVIĆ JELENA, PETROVIĆ T, STOJANOV I i VELHNER MAJA
}

\section{SADRŽAJ}

U cilju praćenja koncentracije enzima (alanin aminotransferaze-ALT, aspartat aminotransferaze-AST, laktat dehidrogenaze-LDH, amilaze i kreatin kinaze-CK) u krvi pacova, izazvana je klinička forma sepse uz primenu modela CLP (cekalna ligacija i punktura). Eksperimenti su izvedeni kod mužjaka pacova Wistar soja, 
prosečne telesne mase $215 \pm 25 \mathrm{~g}$. Pacovi su bili podeljeni u četiri grupe. Kod prve tri grupe ( $n=28 /$ grupa), sepsa je izazvana mešanom (MK) i čistim kulturama bakterija Escherichia coli (EC) i Staphylococcus aureus (SA), dok je u grupi od 20 kontrolnih životinja urađena samo abdominalna incizija (lažna operacija). Krv je uzimana u terminima od 12, 24, 72 i 120 sati.

Tokom eksperimentalnog protokola, u serumu pacova sa sepsom su zabeležene značajne promene u koncentraciji svih praćenih enzima. U terminu od 12 sati je utvrđeno signifikantno povećanje vrednosti ALT (kod svih pacova sa sepsom), AST i LDH (MK), a smanjenje koncentracije amilaze (EC, SA). Isto tako, 24 sata od CLP procedure je zabeleženo signifikantno smanjenje vrednosti amilaze (MK), ali i AST (SA), dok su vrednosti LDH značajno varirale, od povišenih (EC, SA) do sniženih (MK). $U$ ispitivanim terminima od 72 i 120 sati je zabeleženo smanjenje koncentracije gotovo svih praćenih enzima, a signifikantno niže vrednosti su utvrđene za ALT (MK), AST (SA, EC ) i amilazu (SA). U svim ispitivanim terminima, razlike u srednjim vrednostima CK nisu dostizale stepen statističke značajnosti. 